Rizki Briandana, Rustono Farady Marta, Azman Azwan Azmawat:

Reflection on the Identity of the Outermost Indonesian Community on Sebatik Island through

Malaysian Television Broadcasts

Refleksi Identitas Masyarakat Terluar Indonesia di Pulau Sebatik melalui Siaran Televisi Malaysia

\title{
Reflection on the Identity of the Outermost Indonesian Community on Sebatik Island through Malaysian Television Broadcasts
}

\section{Refleksi Identitas Masyarakat Terluar Indonesia di Pulau Sebatik melalui Siaran Televisi Malaysia}

\author{
Rizki Briandana ${ }^{1}$, Rustono Farady Marta ${ }^{2}$, Azman Azwan Azmawati ${ }^{3}$ \\ ${ }^{1}$ Fakultas Ilmu Komunikasi, Universitas Mercu Buana, Jln. Meruya Selatan No.1, Jakarta Barat* \\ Email: rizki.briandana@mercubuana.ac.id \\ ${ }^{2}$ Fakultas Ilmu Komunikasi, Universitas Bunda Mulia, Jln. Lodan Raya No.2, Jakarta Utara \\ Email rmarta@bundamulia.ac.id \\ ${ }^{3}$ School of Communication, Universiti Sains Malaysia, Gelugor Penang, Malaysia \\ Email:azwan@usm.my
}

Masuk tanggal : 31-01-2021, revisi tanggal : 13-07-2021, diterima untuk diterbitkan tanggal : 17-08-2021

\begin{abstract}
This study aims to analyze the interpretation of Indonesian people in Sebatik Island towards Malaysian television programs. The Sebatik community is a marginalized community who does not have access to Indonesian television broadcasts. To get Indonesian television broadcasts, they have to buy satellite dishes which the majority of the people of Sebatik Island cannot afford. But on the other hand there is a leak of Malaysian television broadcasts in the Sebatik Island area. In this case, they rely on Malaysian television broadcasts which are very accessible at all times. This situation continued for many years and Malaysian television broadcasts became the main source of communication media. This study uses the theory of Interpretive Communities, Stanley Fish. The methodology used in this study is reception analysis through focus group discussions, and observation as a data collection technique. Focus Group Discussion was conducted on the people of Sebatik Island who met the criteria in the study. The results showed that Malaysian television broadcasts were used as the main television broadcast of the Sebatik community in their daily lives. Malaysian television which contains the values and meanings of the Malaysian state is interpreted by the Indonesian people on the border of Sebatik Island. The interpretation results show that life in Malaysia is an ideal and perfect life for the people of Sebatik Island.
\end{abstract}

Keywords: audience, identity, Indonesia-Malaysia border, Sebatik Island, television

Abstrak

Penelitian ini bertujuan untuk menganalisis interpretasi masyarakat Indonesia di Pulau Sebatik terhadap program televisi Malaysia. Masyarakat Sebatik adalah masyarakat terpinggir yang tidak memiliki akses siaran televisi Indonesia. Untuk mendapatkan siaran televisi Indonesia, mereka harus membeli parabola yang harganya tidak mampu dibayar oleh mayoritas masyarakat Pulau Sebatik. Namun disisi lain terdapat kebocoran siaran televisi Malaysia di kawasan Pulau Sebatik. Dalam hal ini, mereka mengandalkan siaran televisi 
Malaysia yang sangat mudah diakses setiap saat. Situasi ini berlangsung selama bertahuntahun dan siaran televisi Malaysia menjadi sumber utama media komunikasi. Penelitian ini menggunakan teori Interpretive Communities, Stanley Fish. Metodologi yang digunakan dalam penelitian ini adalah analisis resepsi melalui focus group discussion, dan observasi sebagai teknik pengumpulan data. Focus Group Discussion dilakukan terhadap masyarakat Pulau Sebatik yang memenuhi kriteria dalam penelitian. Hasil penelitian menunjukkan bahwa siaran televisi Malaysia digunakan sebagai siaran televisi utama komunitas Sebatik dalam kesehariannya. Televisi Malaysia yang bermuatan nilai dan makna negara Malaysia di interpretasi oleh masyarakat Indonesia di perbatasan Pulau Sebatik. Hasil interpretasi menunjukan, kehidupan yang ada di Malaysia merupakan kehidupan yang ideal dan sempurna bagi masyarakat Pulau Sebatik.

Kata Kunci: identitas, penonton, perbatasan Indonesia-Malaysia, Pulau Sebatik, televisi

\section{Pendahuluan}

Media dan komunikasi merupakan salah satu elemen sentral dalam kehidupan modern, dapat ditemui di mana saja, kapan saja dan menjadi bagian tak terpisahkan dari pengalaman kontemporer masyarakat, sehingga masyarakat saat ini hidup dalam dunia yang semakin dimediasi (Gauntlett, 2003). Flew (2011) menegaskan bahwa kehidupan masyarakat saat ini menempatkan media sebagai bagian penting dalam kehidupan sehari-hari. Kebutuhan tersebut mengacu pada pemenuhan kebutuhan dasar masyarakat akan media yaitu informasi, pendidikan dan hiburan (Fiske, 2012). Unsur informasi, pendidikan, dan hiburan memainkan peran yang kompleks dan strategis bagi masyarakat dalam membentuk pengalaman sosial dan budaya masyarakat. Rashid et al., (2017) menegaskan bahwa media dan komunikasi merupakan elemen penting dalam kehidupan masyarakat karena masyarakat saat ini hidup di dunia yang semakin bergantung pada media dalam kehidupan sehari-hari.

Praktisi media memahami bahwa media dapat dipelajari berdasarkan dua pandangan; (1) dari sisi mikro teori komunikasi massa; (2) melihat hubungan antara media dan masyarakat luas serta lembaganya (Marôpo, 2014). Dari sisi mikro teori komunikasi massa melihat hubungan antara media dan masyarakat sebagai kelompok atau individu yang menggunakan media. Sisi ini menunjukkan hubungan antara media dan audiensnya. Fokus utama praktisi di sini terletak pada dampak individu dan kelompok dari transaksi dengan media. Sedangkan pandangan kedua, melihat hubungan antara media dengan masyarakat umum dan lembaganya, hal ini disebut sebagai teori komunikasi massa sisi makro. Disini para praktisi media tertarik pada hubungan antara media dan masyarakat khususnya bagaimana posisi media dalam masyarakat antara struktur sosial dan media (Chopra, 2011; Marôpo, 2014).

Kim (2008); Ravi \& Guru (2016); Wahab (2012) menyatakan bahwa media dapat merepresentasikan identitas dalam suatu masyarakat. Media menjadi wadah dalam mengembangkan wacana identitas yang terkandung melalui muatan informasi dan citra. Media menghadapi tantangan tidak hanya dalam menyebarkan informasi kepada publik tetapi juga sebagai platform untuk menumbuhkan citra di masyarakat 
Rizki Briandana, Rustono Farady Marta, Azman Azwan Azmawat:

Reflection on the Identity of the Outermost Indonesian Community on Sebatik Island through Malaysian Television Broadcasts

Refleksi Identitas Masyarakat Terluar Indonesia di Pulau Sebatik melalui Siaran Televisi Malaysia

(Y. Kim, 2008). Dalam hal ini media dapat berperan penting dalam persatuan bangsa karena media juga turut mengapresiasi berbagai elemen yang ada di masyarakat untuk menjamin persatuan bangsa (Marta \& Monica William, 2016).

Dalam perkembangan arus globalisasi dan teknologi media, khalayak melihat media khususnya televisi sebagai sumber utama untuk mendefinisikan, membentuk dan mengembangkan kembali jati diri khalayak (Fauzi \& Fasta, 2020). Hal ini karena televisi memberikan gambaran dan makna kepada khalayak (Chopra, 2011; Livingstone \& Markham, 2008). Media, khususnya televisi, dapat menonjolkan dan membangkitkan beberapa aspek identitas budaya seseorang, misalnya melalui penggambaran seni yang mengandung tema budaya tertentu dengan pertunjukan musik yang diidentikkan dengan kelompok budaya tertentu melalui berbagai pengalaman dengan orang atau media lain (Briandana \& Ibrahim, 2015; Kitley, 2000). Semakin kuat isi identitas komunitas di televisi, maka perbedaan antara identitas dan nilai budaya yang terkandung dalam program televisi bisa menjadi hal yang perlu dikaji lebih detail. Hal ini berawal dari pendapat Fiske (2012) bahwa dalam masyarakat yang dipengaruhi oleh mass-mediated society, masyarakat dapat membangun identitas yang bukan atas pilihannya sendiri melainkan dengan mengubah materi, seperti: gambar, cerita, tokoh, lelucon, nyanyian, ritual, dan mitos dari budaya populer dengan memberikan bentuk ekspresif pada berbagai pengalaman hidup komunitasnya sendiri (Rismayanti, 2019).

Dari aspek konseptual, Mastro et al., (2008) dan Hauser (2012) berpendapat bahwa masyarakat menggunakan media dengan berbagai cara dan untuk kebutuhan yang berbeda. Hal ini mengacu pada kegiatan interpretasi komunitas dimana Brunsdon \& Morley (2005) menyatakan bahwa masyarakat dapat memanfaatkan pesan dan makna yang diperoleh melalui program televisi untuk memahami aktivitas kehidupan sehari-hari yang mereka lakukan. Dalam hal ini, masyarakat menginterpretasi berdasarkan pengalaman mereka (Briandana \& Ibrahim, 2015). Masyarakat juga secara aktif dan bebas menginterpretasi makna melalui teks yang ditampilkan pada media (Piazza \& Haarman, 2016; Tanjung \& Marta, 2018).

Televisi sebagai salah satu media utama memiliki kemampuan untuk membangkitkan beberapa aspek jati diri pada diri seseorang (S. Kim, 2009). Misalnya televisi menunjukkan budaya yang diidentifikasi oleh kelompok budaya (Briandana \& Azmawati, 2021). Dengan demikian, televisi merupakan media penting dalam proses pembentukan identitas (Hanana, Tirta, Roem, \& Lestari, 2020). Dalam hal ini, televisi memiliki peran dalam penyedia konten melaui gambar dan makna untuk proses konstruksi identitas (Livingstone, 2013). Kemudian proses ini dimaknai dan menjadi dasar dalam pembentukan identitas komunitas (Gorton, 2009).

Teknik pemasaran dari televisi tak terpungkiri efektif mendorong perilaku khalayaknya bahkan ditengah akselerasi dunia digital. Iklan televisi berperan penting dalam konstruksi nilai merek kepada khalayak sebagai strategi pemasaran (Marta \& Septyana, 2015). Melalui pemasaran iklan televisi, nilai merek dan publisitas merek akan menciptakan sebuah identitas merek kepada khalayak yang menjadi urgensi bisnis kekinian (Latukolan, Marta, \& Engliana, 2021). Efektifitas komunikasi 
pemasaran menggunakan televisi juga terbukti oleh iklan Mie Sedaap dimana frekuensi periklanan dapat mendorong perilaku konsumen untuk mencoba produk. Frekuensi iklan juga didukung oleh kreatifitas dan kualitas pesan untuk menguatkan identitas produk dalam pangsa pasar (Sukmana, Achmad, \& ZA, 2018).

Televisi tentunya memiliki sisi gelap tersendiri dimana terdapat komodifikasi Pegawai Negeri Swasta di Indonesia dalam Tes Karakteristik Pribadi (TKP). Sejumlah kebocoran informasi soal tes karakteristik tersebut terbukti berperan sebagai titik pengelabuan para penguji Pegawai Negeri Swasta yang ditujukan untuk kepentingan individu (Yudha, Marta, \& Panggabean, 2021). Teknik tersebut terbukti menjadi fabrikasi identitas calon PNS yang jauh dari harapan tes karakteristik yang dititis. Identitas yang dirancang melalui kebocoran informasi bertolak-belakang dengan identitas bangsa yang diciptakan berdasarkan Pancasila (Marta, 2017).

Khalayak melakukan interpretasi dipengaruhi oleh makna sosial dari komunitas itu sendiri (Mcmillin, 2016). Pada hakikatnya makna identitas dan budaya yang ditampilkan melalui tayangan televisi adalah modal berharga dalam proses pembentukan identitas suatu kelompok masyarakat atau komunitas (Rofil, Syed, \& Hamzah, 2015). Oleh karena itu, media massa memegang peranan penting dalam upaya mempersatukan bangsa untuk turut menumbuhkan berbagai elemen yang ada di masyarakat guna menjamin keutuhan suatu bangsa (Konieczna, Mattis, Tsai, Liang, \& Dunwoody, 2014).

Melalui berbagai pandangan di atas dapat disimpulkan tentang hubungan antara penonton dengan media, khususnya televisi yang bersifat interaksional. Barker \& Mathijs (2012) memberikan pendapat bahwa khalayak secara aktif menginterpretasi teks pada program televisi yang ditonton (Lindsey, 2015). Pada dasarnya identitas khalayak dapat menjadi hal yang berpengaruh dalam proses interpretasi terhadap isi media tersebut, belum lagi media yang diraih adalah media asing yang mengusung isi jati diri yang tidak sesuai dengan apa yang khalayak di komunitasnya (Karim, Mariappan, \& Peters, 2016).

Terkait dengan perbedaan latar belakang budaya identitas dalam konten televisi, terdapat keadaan penonton dan relasi media yang menarik dan unik di kawasan perbatasan Indonesia-Malaysia. Audiens Indonesia di wilayah perbatasan berada dalam situasi di mana mereka tidak memiliki akses ke media lokal dalam waktu yang lama. Menurut Riza (2014; Widiastuti (2015; Yusuf (2015)) saluran media publik televisi dan radio yang dapat digunakan oleh masyarakat perbatasan dari negara tetangga, Malaysia.

Polemik perbedaan budaya juga dicerminkan melalui iklan Bukalapak yang ditayangkan dalam televisi dimana terdapat sebuah representasi supremasi kulit putih dalam iklan versi Pengakuan: Awalnya Coba-Coba, Jadi Untung Terus. Ideologi ini menyembunyikan unsur rasisme dan mempromosikan pemikiran supremasi kulit putih di Indonesia tanpa disadari oleh khalayak yang menyaksikan (Umarela, Dwityas, \& Zahra, 2020). 
Rizki Briandana, Rustono Farady Marta, Azman Azwan Azmawat:

Reflection on the Identity of the Outermost Indonesian Community on Sebatik Island through Malaysian Television Broadcasts

Refleksi Identitas Masyarakat Terluar Indonesia di Pulau Sebatik melalui Siaran Televisi Malaysia

Ketergantungan masyarakat Indonesia di Pulau Sebatik terhadap siaran televisi Malaysia disebabkan sulitnya mendapatkan akses atau sinyal siaran televisi dari Indonesia (Yusuf, 2015). Masyarakat Indonesia yang berada di Pulau Sebatik dapat mengakses siaran program televisi Indonesia namun dengan syarat menggunakan antena parabola atau membayar biaya bulanan melalui televisi kabel. Nilai tersebut dianggap terlalu berat bagi masyarakat Indonesia di Pulau Sebatik yang sebagian besar mereka adalah petani dan buruh (Abdullah \& Sari, 2014; Mulyana \& Yaputra, 2020).

Masyarakat Indonesia di perbatasan Pulau Sebatik bisa mendapatkan saluran televisi dari Malaysia secara gratis atau FTA (free-to-air) dengan membeli antena standar dan mendapatkan kualitas siaran yang baik (Sukamto, 2012). Terdapat tiga saluran televisi (TV1, TV2, TV3) dan 18 saluran Radio (Widiastuti, 2015; Yusuf, 2015).

Masyarakat Indonesia di Pulau Sebatik adalah masyarakat marginal yang memiliki keterbatasan pada berbagai aspek (Hafif, 2014). Berdasarkan data Puslitbang LPP RRI, 62\% penduduk Indonesia di Pulau Sebatik bekerja di Malaysia sebagai pedagang, buruh, pembantu rumah tangga dan petani (Hafif, 2014). Selain itu, masyarakat Indonesia di Pulau Sebatik juga mengalami berbagai keterbatasan dari aspek infrastruktur, pendidikan, dan kesehatan (Ghafur, 2018; Siregar, Sutiadi, \& Epin, 2019).

Kajian media yang secara khusus melihat hubungan antara media dan khalayak di perbatasan Indonesia-Malaysia hingga saat ini jarang dilakukan. Banyak penelitian yang telah dilakukan di daerah perbatasan Indonesia dan Malaysia dalam kurun waktu lima tahun terakhir yang dimulai dari berbagai topik dan melibatkan berbagai disiplin ilmu. Diantara studi yang telah dilakukan adalah fokus pada Keamanan Nasional di Wilayah Perbatasan Indonesia: Studi Kasus Pulau Sebatik dan Tawau (Indonesia-Malaysia) (Siregar et al., 2019); Ketahanan Sosial Masyarakat Di Perbatasan: Studi Kasus Di Pulau Sebatik (Ghafur, 2018); Dinamika Masyarakat Perbatasan (Eksistensi Perantau Bugis di Pulau Sebatik Kalimantan Utara: Perspektif Cultural Studies) (Saleh, 2015); Communication Strategy Of Islamic Extension In The Indonesian-Malaysia Border Region (Setiawan, 2019); National Strength On Construction Of International Freight Terminal In Entikong Indonesia (Elyta \& Saing, 2019). Selanjutnya penelitian ini diharapkan dapat mengisi kekosongan atau gap dalam bidang Ilmu Komunikasi khususnya kajian media dengan tujuan mengungkap proses interpretasi teks media asing dengan kondisi khusus di perbatasan.

Dari perspektif kajian media dan komunikasi, perlu dilakukan penelitian khusus terkait interpretasi masyarakat perbatasan yang dapat mempengaruhi proses interaksinya dengan konten media, khususnya siaran yang berasal dari luar negeri yang ditonton setiap hari. Sesuai dengan sudut pandang sosial budaya, khususnya teori interpretive communities, karakter identitas yang dimiliki oleh khalayak Indonesia merupakan bagian dari masyarakat perbatasan yang dipengaruhi oleh proses penafsiran konten media asing yang digunakan sehari-hari (Marta \& Fernando, 
2020). Perbedaan dan keunikan budaya dan identitas masing-masing kedua negara berinteraksi satu sama lain dalam hubungan antara penonton dan media. Berdasarkan pemaparan diatas, penelitian ini bertujuan untuk menganalisis bagaimana penonton Indonesia di perbatasan Indonesia-Malaysia menginterpretasi teks dalam program televisi asing berdasarkan identitas nya (Sasongko \& Marta, 2018).

Untuk mengkaji proses interpretasi teks media yang dilakukan oleh khalayak Indonesia di Pulau Sebatik digunakan analisis resepsi. Analisis resepsi yaitu suatu pendekatan yang bertujuan untuk melihat bagaimana khalayak secara aktif menafsirkan teks di televisi sesuai dengan posisi sosial dan budayanya (Brunsdon \& Morley, 2005). Analisis resepsi mengacu pada perbandingan antara analisis tekstual media dan khalayak, yang interpretasinya mengacu pada konteks, seperti setting budaya dan konteks pada konten media (Briandana, 2016).

McQuail (2010) menyatakan bahwa khalayak merupakan bagian dari komunitas interpretatif yang aktif dalam menafsirkan pesan dan menghasilkan makna. Fish, (2004) dan Linder \& Gentile (2009) berpendapat bahwa makna berasal dari teks yang tidak sepenuhnya subjektif; kecuali teks menjadi bermakna karena berbagai strategi penafsiran yang dilakukan oleh anggota komunitas (Littlejohn \& Foss, 2009).

Penelitian resepsi adalah sebuah metode yang sering digunakan untuk memahami hubungan antara media dan khalayak di seluruh dunia. David Morley sebagai salah satu tokoh kunci dalam studi resepsi melakukan penelitian di London pada tahun 1983. Studi yang dilakukannya merupakan studi yang mencoba melihat pada program Nationwide. Dia memilih untuk melakukan studi tentang rencana Nationwide dan sampai pada kesimpulan bahwa tidak hanya kelas sosial dan ekonomi yang mempengaruhi interpretasi penonton. Namun, gender dan latar belakang etnis juga memiliki pengaruh yang sama pentingnya terhadap status ekonomi penonton (Bignell \& Lacey, 2014).

Kajian resepsi yang dilakukan di berbagai negara di dunia berhasil menggambarkan bagaimana nilai, gagasan, dan relevansi khalayak sebagai bagian dari komunitas masyarakat mempengaruhi proses interpretasi yang dilakukan pada teks media. Beberapa studi tersebut adalah Telenovela Reception in Rural Brazil: Gendered Readings and Sexual Mores (La Pastina, 2004); Choosing Commercial Television's Identities in India : A Reception Analysis (Mcmillin, 2016); Transnational Audience Reception as a Theater of Struggle: Young Filipino Women's Reception of Korean Television Dramas (Espiritu, 2011); dan Transformations through Twitter: The England riots, television viewership and negotiations of power through media convergence (Bennett, 2012). Keseluruhan studi menunjukkan bahwa penonton sebagai pihak yang secara aktif menafsirkan teks media tidak dapat dilepaskan dengan posisi dan relevansinya dalam lingkungan sosial dan budaya tempat mereka berasal. Merujuk pada penelitian-penelitian diatas, bahwa keunikan utama dari penelitian ini adalah sejauh ini penelitian dengan metode analisis resepsi selalu dilakukan di kota-kota besar atau di tempat yang berkembang saja, namun 
Rizki Briandana, Rustono Farady Marta, Azman Azwan Azmawat:

Reflection on the Identity of the Outermost Indonesian Community on Sebatik Island through Malaysian Television Broadcasts

Refleksi Identitas Masyarakat Terluar Indonesia di Pulau Sebatik melalui Siaran Televisi Malaysia

penelitian ini dilakukan di tempat yang marginal dan terpencil dengan demografi masyarakat beragam yang berasal dari suku Jawa, Bugis, Flores dan Dayak-Melayu.

Berdasarkan pemaparan diatas, tujuan dari penelitian ini adalah menganalisis interpretasi penonton Indonesia di Pulau Sebatik terhadap drama dari saluran televisi Malaysia.

\section{Metode Penelitian}

Metode analisis resepsi digunakan dalam penelitian ini. Metode analisis resepsi bertujuan untuk mengkaji penafsiran atau interpretasi khalayak. Interpretasi penonton dilihat dengan mengkaji latar belakang budaya dan sosial di kalangan khalayak (Brunsdon \& Morley, 2005). Dalam hal ini adalah khalayak atau masyarakat yang berada di Pulau Sebatik, perbatasan Indonesia dan Malaysia. Peneliti menggunakan paradigma konstruktivisme. Paradigma ini digunakan untuk menafsirkan dan memahami alasan penonton atas tindakan sosial yang dilakukannya, yaitu cara penonton membangun kehidupannya dan makna yang mereka berikan terhadap kehidupan tersebut (Barker \& Mathijs, 2012). Analisis resepsi mencoba untuk membuka sejauh mana pemahaman khalayak, apa yang telah mereka rasakan. Analisis Resepsi dikenal sebagai analisis perbandingan tekstual dari sudut pandang media dan audiens (Brunsdon \& Morley, 2005).

Penelitian dilakukan terhadap khalayak Indonesia di wilayah perbatasan Indonesia-Malaysia. Peneliti menggali data dan menganalisis dari sudut pandang informan, sehingga akan terlihat bagaimana dinamika sosial budaya dalam membentuk pemahaman informan dalam menafsirkan teks di televisi.

Focus group discussion (FGD) dan observasi digunakan sebagai teknik pengumpulan data terhadap penonton Indonesia di wilayah perbatasan IndonesiaMalaysia dalam proses interpretasi melalui program televisi Malaysia yang mereka tonton. Dalam penelitian ini proses pengambilan sampel akan difokuskan pada dua desa yaitu Desa Aji Kuning serta Desa Bukit Harapan. Justifikasi pemilihan desa tersebut karena kedua desa ini tidak memiliki akses siaran televisi Indonesia dalam jangka yang lama dan penduduk di desa tersebut berasal dari suku yang beragam, yaitu Bugis, Jawa, dan Melayu. Adapun proses pengambilan data dilaksanakan selama dua belas hari, mulai pada 25 Agustus sampai 31 Agustus 2019.

Subjek penelitian ini adalah masyakarat Indonesia di Pulau Sebatik, dimana terdapat adalah dua belas orang yang menjadi informan. Adapun justifikasi pemilihan informan didasarkan kepada kriteria-kriteria sebagai berikut: 1) Informan adalah warga negara Indonesia dan merupakan bagian dari masyarakat Pulau Sebatik; 2) Informan yang kesulitan mengakses televisi Indonesia dan menonton siaran televisi Malaysia; 3) Informan menonton acara televisi Malaysia dalam waktu lama (minimal 1 tahun); 4) Informan berasal dari suku yang beragam yang ada di Pulau Sebatik. 
Dari dua belas yang menjadi informan masing-masing terdiri dari tiga informan yang berasal dari suku Bugis, Jawa, Flores dan Dayak-Melayu. Informan ini dipilih ketika peneliti melakukan studi pendahuluan (Pra-Research) untuk mengkategorikan masyarakat Indonesia di perbatasan Pulau Sebatik yang menonton program televisi Malaysia.

Program televisi Malaysia yang dianalisis merujuk kepada program yang paling sering ditonton oleh masyakarat Pulau Sebatik yaitu: Sembilu, Saya Bukan Isteri Dia dan Tiga Hari Menanti Suka yang tayang di TV 1 dan TV 3 Malaysia. Adapun pemilihan drama ini didasari kepada hasil studi pendahuluan (Pra-Research) yang dilakukan peneliti, dimana sebagian besar warga di Pulau Sebatik paling sering menonton ketiga drama ini dan ketiga drama ini favorit bagi masyakarat sekitar. Studi pendahuluan (Pra-Research) dilakukan oleh peneliti sebelum pengumpulan data utama dengan door-to-door ke rumah warga yang direkomendasikan oleh Kepala Desa.

Adapun ketiga drama Malaysia (Sembilu, Saya Bukan Isteri Dia dan Tiga Hari Menanti Suka) memiliki plot cerita yang masing-masing hampir sama. Ketiga drama ini mengedepankan romantisme dalam rumah tangga yang diwarnai konflik perselingkuhan dan penipuan. Dengan latar belakang kehidupan yang mewah dan kaya serta dominasi pemain dengan fisik yang sempurna, ketiga drama ini banyak dimintasi oleh masyarakat Indonesia di Pulau Sebatik.

\section{Hasil Penemuan dan Diskusi}

Berdasarkan hasil data, kehidupan sosial yang dipaparkan dalam program televisi Malaysia, menjadi rujukan yang sempurna bagi masyarakat Pulau Sebatik. Masyarakat Pulau Sebatik menginterpretasi konten televisi yang dinilai jauh lebih baik dari realitas kehidupan masyarakat yang sebenarnya. Selain itu, hasil interpretasi menunjukan informan menikmati segala bentuk konten yang dipaparkan dalam acara drama Malaysia. Informan merasa terharu, sedih dan tersentuh jika melihat acting yang sedih ataupun gembira. Hal ini merupakan pengalaman menonton yang menjadi kesenangan bagi informan. Hasil data juga menunjukan bahwa informan menikmati aktivitas menonton sebagai sarana hiburan, dan informasi. Mereka juga menyatakan bahwa merasa puas apabila dapat berdiskusi tentang acara televisi pada saat berlangsung atau setelah selesai.

Acara drama televisi Malaysia kemudian menjadi bahan obrolan atau diskusi dengan anggota keluarga dan teman. Dalam konteks ini, siaran televisi Malaysia memiliki peran yang besar dalam hiburan, pendidikan, dan informasi. Berdasarkan pandangan informan atas informasi yang diperoleh dari televisi, informasi tersebut digunakan sebagai referensi dalam menjalankan kehidupan sehari-hari. Hal ini dinyatakan oleh informan sebagai berikut:

"Saya sangat suka dengan drama televisi Malaysia. Mereka memiliki acting yang bagus, pelakonnya ganteng dan cantik, serta cerita juga bagus. Untuk acara televisi Indonesia saya tidak tau, kerana tidak pernah nonton” (Informan 1, Agustus 2019). 
Rizki Briandana, Rustono Farady Marta, Azman Azwan Azmawat:

Reflection on the Identity of the Outermost Indonesian Community on Sebatik Island through Malaysian Television Broadcasts

Refleksi Identitas Masyarakat Terluar Indonesia di Pulau Sebatik melalui Siaran Televisi Malaysia

"Bagi saya drama televisi Malaysia itu sangat bagus, menghibur dan tidak membosankan. Berbeda dengan sinetron, episode nya banyak sekali, kita sampai bosan nontonnya dan cerita nya suka mengada-ngada" (Informan 2, Agustus 2019).

"Drama televisi Malaysia yang paling bagus adalah bahasanya, pemainnya, dan kehidupan mereka. Kami kalau menonton itu merasa senang, apalagi kami bisa lihat rumah yang bagus, mobil bagus jalan juga bagus. Berbeda dengan kami disini jalan pun rusak, apalagi kalau habis hujan susah sekali kami” (Informan 3, Agustus 2019).

"Saya hanya bayangkan apa yang ada di televisi pak. Hidup di Malaysia tidak susah, jalan pun bagus, berbeda dengan kami yang ada disini” (Informan 4, Agustus 2019).

"Penggambaran hidup dalam drama televisi Malaysia sangat bagus, berbeda dengan kami yang hidup disini” (Informan 5, Agustus 2019).

Bagi informan kesenangan menonton televisi adalah bentuk hiburan dan sumber informasi utama. Selain itu, masyarakat Indonesia di Pulau Sebatik juga heboh berdiskusi tentang konten program televisi selama atau setelah acara televisi berakhir. Hal ini sejalan dengan pernyataan Litt (2012) yang menjelaskan bahwa bagian penting dari aktivitas menonton televisi adalah pembahasan tentang isi acara televisi yang ditonton sepanjang hari. Bagi sebagian besar informan, menonton televisi adalah proses yang aktif. Mereka tidak hanya duduk diam di depan televisi dan menerima berbagai hal yang disajikan di televisi. Namun, khalayak juga dapat memilih untuk terlibat dalam diskusi terkait konten televisi yang ditonton. Dalam diskusi tersebut mereka membahas isu-isu yang sedang ditayangkan di televisi. Isi tayangan televisi tersebut kemudian menjadi sumber diskusi di kalangan informan. Analisis hasil penelitian menunjukkan bahwa terdapat informan yang membahas tentang konten televisi yang mereka tonton.

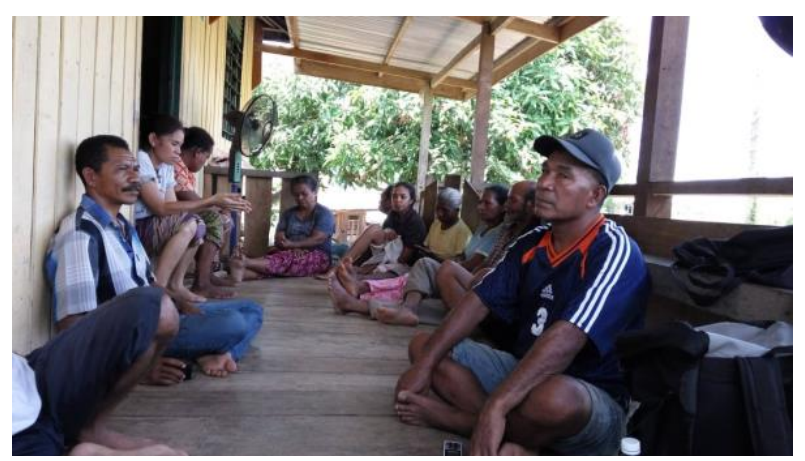

Gambar 1: Masyarakat Pulau Sebatik Berkumpul Setelah Menonton TV

(Sumber: Dokumentasi Peneliti) 
Gambar 1 menunjukan interaksi antara penonton dan televisi merupakan dinamika sosial yang menunjukkan bahwa interaksi tersebut sering dikaitkan dengan situasi kesehariannya. Berdasarkan hasil penelitian, ditemukan bahwa bagi masyarakat Pulau Sebatik teks televisi memiliki peran penting dalam kehidupan sosial mereka. Temuan ini mendukung penelitian yang dilakukan Brunsdon \& Morley (2005) yang menyatakan bahwa konten televisi diinterpretasikan sesuai dengan preferensi mereka. Informan menyatakan bahwa informasi yang diperoleh dari tayangan televisi Malaysia digunakan sebagai materi diskusi atau obrolan saat berinteraksi di lingkungan masyarakat.

Hasil penemuan menunjukan interpretasi dipandang sebagai proses unik dalam aktivitas menonton televisi. Dalam konteks ini peneliti juga mengkritisi bahwa menonton program televisi bukan lagi melihat tentang dampak yang dapat diberikan oleh media massa melainkan bagaimana pemaknaan yang dibentuk melalui interaksi yang terjadi antara teks televisi dengan penontonnya.

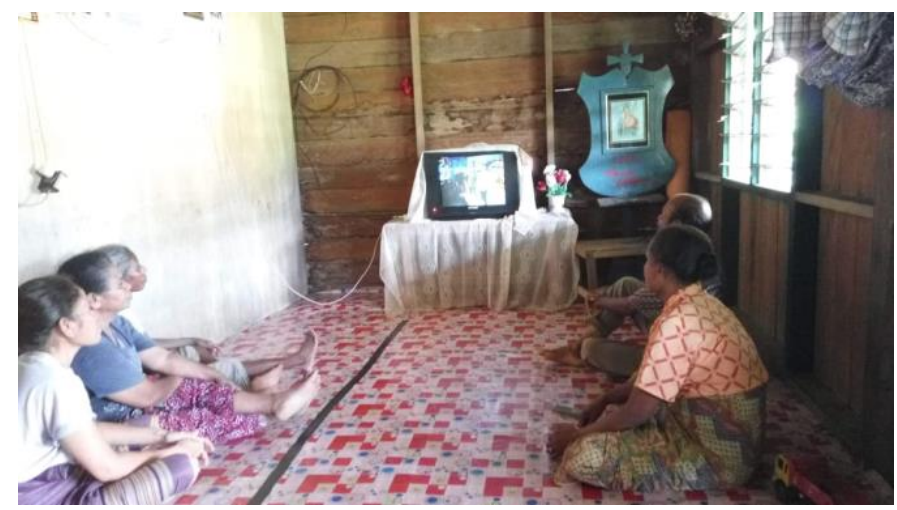

Gambar 2: Masyarakat Indonesia Menonton Televisi Malaysia

(Sumber: Dokumentasi Peneliti)

Interaksi yang terjadi antara penonton Indonesia dengan siaran televisi Malaysia, telah menjadikan kegiatan nonton televisi Malaysia sebagai kegiatan rutinitas yang telah berlangsung pada waktu yang lama. Hal ini diperkuat dengan hasil temuan yang menunjukkan bahwa masyarakat Indonesia di Pulau Sebatik lebih menyukai konten yang dipaparkan dalam drama televisi Malaysia. Bagi mereka budaya Malaysia yang dipaparkan dalam televisi terasa lebih dekat dan hangat. Konten yang disampaikan berisi unsur keindahan dalam kehidupan sosial dengan latar belakang Malaysia.

Selain itu, hasil penelitian juga menunjukkan bahwa masyarakat Pulau Sebatik menikmati dan memiliki pandangan yang positif terhadap konten drama televisi Malaysia. Hasil penemuan ini searah dengan penelitian Triwardani (2013) bahwa interaksi antara televisi dan masyarakat menghasilkan berbagai bentuk aktivitas ekonomi, budaya, dan sosial. Sebagai contoh, penggunaan uang Ringgit 
Rizki Briandana, Rustono Farady Marta, Azman Azwan Azmawat:

Reflection on the Identity of the Outermost Indonesian Community on Sebatik Island through Malaysian Television Broadcasts

Refleksi Identitas Masyarakat Terluar Indonesia di Pulau Sebatik melalui Siaran Televisi Malaysia

dalam aktivitas pasar atau ekonomi masyarakat di perbatasan Pulau Sebatik (Briandana, 2019).

Bagi masyarakat Pulau Sebatik, kegiatan menonton televisi merupakan upayah "lari dari kenyataan" kehidupan mereka. Bagi mereka, semua yang dipaparkan dalam televisi membuat masyarakat Pulau Sebatik sejenak melupakan masalah yang dihadapi dengan membayangkan kehidupan yang sempurna seperti apa yang informan sampaikan:

"Yang dipaparkan dalam drama Malaysia senang kami pak, kami lihat pelakon yang cantik, lihat rumah bagus, jalan yang bagus tidak seperti kami disini, jalan rusak, listrik sering mati" (Informan 6, Agustus 2019).

"Bahagia ketika melihat drama Malaysia pak, apalagi selepas pulang kerja dari sawah, penggambaran rumah mewah, mobil mewah, kami membayangkan indah sekali negara sebrang itu pak" (Informan 5, Agustus 2019).

"Bagi saya drama yang ditonton ini bagus sekali pak, kalau sudah nonton saya kadang kala suka nangis, kadang-kadang suka kesal juga. Sepertinya terbawa suasana dalam drama" (Informan 7, Agustus 2019).

"Saya memang dari anak-anak sampai sekarang selalu suka dengan drama Malaysia. Bahkan kalau ada drama favorit bisa menonton sampai larut malam. Pernah juga saya nonton sampai nangis-nangis karena lihat adegan dalam drama" (Informan 8, Agustus 2019).

"Saya sangat sering perasaan nya tersentuh kalau nonton drama, kadang menangis, kadang emosi" (Informan 9, Agustus 2019).

"Yang paling saya suka adaah melihat pelakon Malaysia, cara main nya juga bagus, tidak pura-pura. Sering juga saya senyum kalau nonton, berasa senang juga ada, bahkan menangis juga sering" (Informan 10, Agustus 2019).

"Bagi kami drama di televisi Malaysia adalah hiburan. Hanya ini kesenangan kami, kami dibuat tertawa, sedih dan kesal. Jadi betul-betu hiburan utama kami kalau pulang kerja dari ladang” (Informan 11, Agustus 2019).

"Saya selalu suka lagu pop yang ada pada drama Malaysia, bahkan saya hafal. Kalau lagu Malaysia saya suka lagu otai” (Informan 12, Agustus 2019).

Bagi masyarakat Pulau Sebatik, siaran televisi Malaysia telah berhasil memenuhi kebutuhannya pada aspek hiburan, pendidikan, dan informasi. Pendek kata, masyarakat Indonesia di Pulau Sebatik memiliki ketergantungan terhadap program televisi Malaysia. Dari berbagai nilai yang ada pada program drama televisi Malaysia, masyarakat Pulau Sebatik dapat memilih apa yang mereka terima, apa yang mereka tolak dan bahkan mereka juga dapat bernegosiasi dengan keadaan mereka yang tinggal wilayah perbatasan. Dengan demikian, proses interpretasi masyarakat 
Pulau Sebatik mengacu pada konsep Fish (2004) yang menyatakan bahwa proses interpretasi tidak bersifat benar dan absolut. Selanjutnya Fish (2004) menyatakan bahwa interpretasi tidak bersifat objektif selalu dikonstruksi secara sosial. Interpretasi yang dihasilkan oleh individu sering kali dikaitkan dengan konteks sosial atau latar belakang tempat mereka tinggal (Meisyanti \& Rahmawati, 2021). Menurut Fish (2004) hal ini adalah konsep komunitas interpretatif dan penerjemahan yang menjadi bagian dari komunitas setelah dicapai kesepakatan atas suatu konstruksi. Begitu pula dengan cara hidup masyarakat sebenarnya bukan merupakan cerminan dari realitas di luar masyarakat tetapi sebuah konstruksi yang dihasilkan berdasarkan kesepakatan atas realitas yang mereka miliki dan tetap kuat selama masyarakat tetap percaya diri akan hal tersebut. Hal ini sejalan dengan penelitian Espiritu (2011) yang menekankan proses proses menghasilkan makna. Khalayak terlibat secara aktif dalam proses pemaknaan melalui proses interpretasi yang berkelanjutan. Hal ini merupakan interaksi antara teks dan penonton yang dilandasi oleh adanya perbedaan budaya antara masyarakat Indonesia di Pulau Sebatik dengan konten yang dibuat dalam drama televisi Malaysia.

Hasil analisis menunjukkan adanya suasana emosional seperti perasaan sedih, senang, bangga, kesal akibat akting yang ditampilkan pada program drama Malaysia. Dalam hal ini, apabila individu dipengaruhi secara emosional oleh aktivitas menonton drama, berarti penonton telah mencapai level emosi yang dalam. Tingkat emosi mendalam ini adalah bentuk dari ekspresi psikologis seseorang ketika mendalami suatu perasaan (Bignell \& Lacey, 2014). Level emosional ini juga sejalan dengan konsep yang dilakukan oleh Ang (2013) bahwa penonton dapat menjadi emosional karena adanya hubungan kuat antara konten drama dengan khalayaknya. Masyarakat Indonesia di Pulau Sebatik dapat diidentifikasi sebagai penonton setia konten drama Malaysia karena mengetahui apa yang dipaparkan dalam program drama tersebut secara mendalam.

Berdasarkan pola menonton televisi terlihat bahwa tidak semua program drama televisi Malaysia yang ditayangkan menarik bagi informan. Informan ditemukan juga selektif dalam menonton program televisi. Hal ini dilihat dari aktivitas menonton yang ditunjukkan bahwa mereka telah melakukan proses negosiasi. Dalam konteks ini, masyarakat Pulau Sebatik bukan pada posisi negosiasi, dominan dan berbeda pendapat sebagaimana konsep yang dikemukakan oleh (Rofil et al., 2015). Proses negosiasi dalam hal ini melihat aspek kontekstual pada pola interaksi antara khalayak dan media. Hal ini melahirkan sebuah dinamika perilaku aktivitas menonton televisi yang berbeda antara informan yang berasal dari latar belakang suku Jawa, Dayak, dan Bugis. Bagi informan yang berasal dari suku Jawa terlihat aktivitas menonton banyak melibatkan dialog antar keluarga ketika menonton. Bagi informan yang berasal dari suku Bugis banyak memiliki aspek emosional dengan kesal dan sedih ketika menonton drama. Sementara bagi informan yang berasal dari suku dayak terlihat lebih banyak diam ketika sedang menonton. 
Rizki Briandana, Rustono Farady Marta, Azman Azwan Azmawat:

Reflection on the Identity of the Outermost Indonesian Community on Sebatik Island through Malaysian Television Broadcasts

Refleksi Identitas Masyarakat Terluar Indonesia di Pulau Sebatik melalui Siaran Televisi Malaysia

Hasil temuan juga menunjukkan bahwa interpretasi terhadap program televisi Malaysia dijadikan sebagai pengalaman untuk membangun identitas dirinya. Hasil interpretasi ini menyebabkan terbentuknya identitas yang unik. Identitas ini merujuk kepada wujudnya percampuran budaya di antara budaya Indonesia dengan budaya Malaysia dalam masyarakat Pulau Sebatik. Percampuran budaya ini dapat dilihat melalui penggunaan bahasa yang bercampur antara Bahasa Indonesia dengan Bahasa Malaysia. Kedua adalah penggunaan produk Malaysia mulai dari pakaian, produkproduk seni, program televisi dan lagu Malaysia. Tentunya hasil percampuran budaya ini merupakan unsur kebaruan yang tidak ditemuan pada penelitian-penelitian sebelumnya. Dalam konteks ini kegiatan menonton drama televisi Malaysia yang diteliti dalam penelitian ini merupakan upaya eksplorasi untuk menemukan informasi yang lebih dalam tentang identitas jati diri seseorang. Hal ini juga mendukung penelitian Morley (2003) yang menyatakan bahwa televisi dapat dilihat sebagai teknologi yang terintegrasi ke dalam konstruksi praktik kehidupan sehari-hari masyarakat.

\section{Simpulan}

Penelitian ini menyimpulkan bahwa masyarakat Pulau Sebatik merupakan masyarakat marjinal yang tidak memiliki akses siaran televisi Indonesia. Namun dalam kasus lain terjadi melimpahnya siaran televisi Malaysia di kawasan perbatasan Sebatik. Siaran televisi Malaysia ini kemudian dijadikan siaran televisi utama oleh masyarakat Pulau Sebatik dalam kesehariannya. Interpretasi adalah pemaknaan yang dilakukan oleh masyarakat Pulau Sebatik yang mengacu pada program drama televisi Malaysia yang mereka tonton setiap hari. Adapun drama Malaysia yang diinterpretasi khalayak dalam penelitian ini adalah Sembilu, Saya Bukan Isteri Dia dan Tiga Hari Menanti Suka. Dalam proses interpretasi ini terdapat hubungan antara televisi dan penonton dalam menafsirkan program televisi Malaysia, bagi mereka drama Malaysia dapat dinikmati dan diterima secara positif. Bagi masyarakat Pulau Sebatik kesenangan menonton televisi adalah bentuk hiburan utama bagi masyarakat perbatasan. Program televisi Malaysia telah menjadi referensi utama dalam kehidupan sehari-hari masyarakat Pulau Sebatik. Dalam hal ini, peran media yang seharusnya dijalankan oleh media Indonesia telah telah diambil oleh media televisi Malaysia.

Rutinitas menonton acara televisi Malaysia tidak hanya menyangkut tingkat frekuensi menonton saja tetapi juga menyangkut perhatian yang diberikan masyarakat Pulau Sebatik terhadap program-program yang diminati. Hal inilah yang menyebabkan terbentuknya pandangan tentang berbagai hal yang ditampilkan dalam konten televisi Malaysia. Masyarakat Pulau Sebatik memiliki pandangan bahwa kehidupan yang ditayangkan pada drama televisi Malaysia merupakan bentuk kehidupan yang sempurna. Ini yang menyebabkan munculnya kekhawatiran bahwa hidup di Malaysia lebih baik dari hidup di Indonesia dan Malaysia adalah negeri impian. 
Penelitian ini diharapkan memberikan kontribusi di bidang komunikasi khusunya media dan khalayak yang berlangsung di daerah-daerah marjinal, mengingat selama ini penelitian tentang media dan audiens masih jarang dilakukan di daerah-daerah yang terpinggir.

\section{Daftar Pustaka}

Abdullah, I., \& Sari, I. P. (2014). Politik identitas masyarakat perbatasan IndonesiaMalaysia: Kasus Badau di Kapuas Hulu, Kalimantan Barat. Jurnal Kawistara, 4(3). https://doi.org/https://doi.org/10.24832/jpnk.v2i1.579

Ang, I. (2013). Watching Dallas: Soap opera and the melodramatic imagination. London: Routledge.

Barker, M., \& Mathijs, E. (2012). Researching world audiences: The experience of a complex methodology. Participations, 9(2), 664-689.

Bennett, L. (2012). Transformations through Twitter: The England riots, television viewership and negotiations of power through media convergence. Participations: The International Journal of Audience and Reception Studies, 9(2), 511-525.

Bignell, J., \& Lacey, S. (2014). British television drama: past, present and future. London: Springer.

Briandana, R. (2016). Televisi Berlangganan dan Identitas Diri: Studi Resepsi Remaja terhadap Tayangan Drama Seri Korea Decendents Of The Sun di KBS World. SIMBOLIKA, 2(1).

Briandana, R. (2019). Television and National Identity: An Ethnography of Television Audience in the Border of Indonesia-Malaysia. Jurnal Ilmu Sosial Dan Ilmu Politik, 23(1), 72-85. https://doi.org/10.22146/ jsp.27205

Briandana, R., \& Azmawati, A. A. (2021). The influx of national identity: "imagined communities" on Indonesian audience in Indonesia and Malaysia frontier. Jurnal Studi Komunikasi (Indonesian Journal of Communications Studies), 5(1), 24. https://doi.org/10.25139/jsk.v5i1.2846

Briandana, R., \& Ibrahim, I. S. (2015). Audience interpretation on Korean TV drama series in Jakarta. Jurnal Komunikasi Borneo, 4(1), 45-55.

Brunsdon, C., \& Morley, D. (2005). The Nationwide Television Studies. London and New York: Routledge.

Chopra, R. (2011). Global media, culture, and identity: Theory, cases, and approaches. London: Routledge.

Elyta, H. A., \& Saing, Z. (2019). National Strength On Construction Of International Freight Terminal In Entikong Indonesia. International Journal of Scientific and Technology Research, 8(3), 10-15.

Espiritu, B. F. (2011). Transnational Audience Reception as a Theater of Struggle: Young Filipino Women's Reception of Korean Television Dramas. Asian Journal of Communication, 21(4), 355-372. 
Rizki Briandana, Rustono Farady Marta, Azman Azwan Azmawat:

Reflection on the Identity of the Outermost Indonesian Community on Sebatik Island through Malaysian Television Broadcasts

Refleksi Identitas Masyarakat Terluar Indonesia di Pulau Sebatik melalui Siaran Televisi Malaysia

Fauzi, E. P., \& Fasta, F. (2020). Modern Muslimah in Media: A Study of Reception Analysis in "Saliha" Program on Net TV. ASPIRATION JOURNAL, 1(2), $135-162$.

Fish, S. (2004). Postmodern Sophistry: Stanley Fish and the Critical Enterprise. New York: SUNY Press.

Fiske, J. (2012). Pengantar ilmu komunikasi. Jakarta: Rajawali Press.

Flew, T. (2011). Rethinking public service media and citizenship: Digital strategies for news and current affairs at Australia's Special Broadcasting Service (SBS). International Journal of Communication, 5(2011), 215-232.

Gauntlett, D. (2003). Media, gender and identity: An introduction. London \& New York: Routledge.

Ghafur, M. F. (2018). Ketahanan Sosial Masyarakat Di Perbatasan: Studi Kasus Di Pulau Sebatik. Masyarakat Indonesia, 42(2), 233-247.

Gorton, K. (2009). Media Audiences: Television, Meaning and Emotion: Television, Meaning and Emotion. Edinburgh University Press.

Hafif, Z. (2014). Peran LPP RRI Indonesia dalam mengkonstruksi identitas nasional Indonesia di wilayah perbatasan. Jakarta: Puslitbang LPP RRI.

Hanana, A., Tirta, N. W., Roem, E. R., \& Lestari, Y. (2020). Sponsor-Oriented Marketing Communication By Padang Tv for Maintaining Local-Cultural Content. Bricolage: Jurnal Magister Ilmu Komunikasi, 6(02), 159. https://doi.org/10.30813/bricolage.v6i02.2155

Hauser, R. (2012). Cultural Identity in a Globalised World? A theoretical approach towards the concept of cultural identity., 1-17.

Karim, H. A., Mariappan, K., \& Peters, D. (2016). Local-Global Media Images, Future Lives: Hybrid Identities Among Rural Sabahan Youths. Malaysian Journal of Media Studies, 18(2), 21-36.

Kim, S. (2009). Interpreting transnational cultural practices: Social discourses on a Korean drama in Japan, Hong Kong, and China. Cultural Studies, 23(5-6), $736-755$.

Kim, Y. (2008). Media, consumption, and everyday life in asia. (Y. Kim, Ed.), Intersections of Media and Communications: Concepts and Critical Frameworks. New York: Routledge.

Kitley, P. (2000). Television, nation and culture in Indonesia. (G. Berchowitz, Ed.). Ohio: Ohio University Center for International Studies.

Konieczna, M., Mattis, K., Tsai, J.-Y., Liang, X., \& Dunwoody, S. (2014). Global journalism in decision-making moments: A case study of Canadian and American television coverage of the 2009 United Nations Framework Convention on Climate Change in Copenhagen. Environmental Communication, 8(4), 489-507.

La Pastina, A. C. (2004). Telenovela Reception in Rural Brazil: Gendered Readings and Sexual Mores. Critical Studies in Media Communication, 21(2), 162-181. 
Latukolan, J. J., Marta, R. F., \& Engliana, E. (2021). When Words Matter: Language Choices and Brand Building on Two Global Coffee Shop Retail Brands in Indonesia. Budapest International Research and Critics Institute (BIRCIJournal): Humanities and Social Sciences, 4(2), 2899-2906. https://doi.org/10.33258/birci.v4i2.1974

Linder, J. R., \& Gentile, D. A. (2009). Is the television rating system valid? Indirect, verbal, and physical aggression in programs viewed by fifth grade girls and associations with behavior. Journal of Applied Developmental Psychology, 30(3), 286-297.

Lindsey, L. L. (2015). Gender roles: A sociological perspective. New York and London: Routledge.

Litt, E. (2012). Knock, knock. Who's there? The Imagined Audience. Journal of Broadcasting \& Electronic Media, 56(3), 330-345.

Littlejohn, S. W., \& Foss, K. A. (2009). Encyclopedia of Communication Theory. Sage Publications.

Livingstone, S. (2013). Making sense of television: The psychology of audience interpretation. London: Routledge.

Livingstone, S., \& Markham, T. (2008). The contribution of media consumption to civic participation 1. The British Journal of Sociology, 59(2), 351-371. https://doi.org/10.1111/j.1468-4446.2008.00197.x

Marôpo, L. (2014). Youth, identity and stigma in the media : From representation to the young audience's perception. Journal of Audience and Reception Studies, 11(1), 199-212.

Marta, R. F. (2017). REFLEKSI HIBRIDITAS BUDAYA DALAM PANCASILA PADA REALITAS DAN MEDIA SEBAGAI IDENTITAS BANGSA. Bricolage: Jurnal Magister Ilmu Komunikasi, 3(01), 1-12. https://doi.org/10.30813/bricolage.v3i01.841

Marta, R. F., \& Fernando, J. (2020). Dialectics of Forgiveness between Ethnic Communities for West Kalimantan Harmony. Jurnal The Messenger, 12(1), 1. https://doi.org/10.26623/themessenger.v12i1.1408

Marta, R. F., \& Monica William, D. M. W. (2016). Studi Terpaan Media Pemasaran Melalui Posting Instagram Terhadap Ekuitas Merek Pelanggan Sumoboo! Jurnal Komunikasi, 8(1), 68-82. https://doi.org/10.24912/jk.v8i1.50

Marta, R. F., \& Septyana, V. (2015). Semiotika Pemasaran pada Brand Value Melalui Sign Berupa Layout Berita dan Iklan Ibadah Haji (Studi Komparasi pada Harian Pos Kota dengan Rakyat Merdeka). Semiotika: Jurnal Komunikasi, 9(2), 482-508.

Mastro, D. E., Behm-Morawitz, E., \& Kopacz, M. A. (2008). Exposure to television portrayals of Latinos: The implications of aversive racism and social identity theory. Human Communication Research, 34(1), 1-27. https://doi.org/https://doi.org/10.1111/j.1468-2958.2007.00311 
Rizki Briandana, Rustono Farady Marta, Azman Azwan Azmawat:

Reflection on the Identity of the Outermost Indonesian Community on Sebatik Island through Malaysian Television Broadcasts

Refleksi Identitas Masyarakat Terluar Indonesia di Pulau Sebatik melalui Siaran Televisi Malaysia

Mcmillin, D. C. (2016). Choosing Commercial Television's Identities in India : A Reception Analysis. Continuum, 4312(March). https://doi.org/10.1080/10304310220121037

McQuail, D. (2010). Mass Communication Theory. London and New York: Sage publications.

Meisyanti, \& Rahmawati, K. (2021). Environmental Communication Strategy in Overcoming Cisadane River Water Pollution. Jurnal Komunikasi, 13(1). https://doi.org/10.24912/jk.v13i1.9307

Morley, D. (2003). Television, audiences and cultural studies. London and New York: Routledge.

Mulyana, D., \& Yaputra, A. (2020). The contestation of cultural claims in online media between Malaysia and Indonesia. Jurnal Studi Komunikasi (Indonesian Journal of Communications Studies), 4(2), 344. https://doi.org/10.25139/jsk.v4i2.2152

Piazza, R., \& Haarman, L. (2016). A pragmatic cognitive model for the interpretation of verbal-visual communication in television news programmes. Visual Communication, 15(4), 461-486.

Rashid, K., Rahman, B. H., \& Butt, A. R. (2017). Media Consumption and National Identity Formation of Adolescents in Pakistan. Journal of Media Studies, 32(1), 1-31. https://doi.org/10.1006/jado.1998.0201

Ravi, B. K., \& Guru, B. P. M. C. (2016). Theoretical foundations of globalization and media management: A new perspective. Educational Research International, $5(4), 22-32$.

Rismayanti, R. (2019). Pembentukan Konsep Diri Remaja Penonton Film Dilan 1990 di Yogyakarta. Jurnal Komunikasi, 18(1), 105-122.

Riza, F. (2014). KPID Kalimantan Barat siapkan roadmap informasi perbatasan.

Rofil, F., Syed, A., \& Hamzah, A. (2015). Televisyen dan pembentukan identiti "Becoming Malay": Television and the construction of female Javanese. Jurnal Komunikasi: Malaysian Journal of Communication, 31(1), 41-58. https://doi.org/10.17576/JKMJC-2015-3101-03

Saleh, M. H. (2015). Dinamika Masyarakat Perbatasan (Eksistensi Perantau Bugis di Pulau Sebatik Kalimantan Utara: Perspektif Cultural Studies). Jurnal Borneo Administrator, 11(1).

Sasongko, Y. P. D., \& Marta, R. F. (2018). Ekspresi Identitas Melalui Relasi Ayah Dan Anak Pada Iklan Youtube Grab Official. Bricolage: Jurnal Magister Ilmu Komunikasi, 4(02), 118. https://doi.org/10.30813/bricolage.v4i02.1656

Setiawan, H. (2019). Communication Strategy Of Islamic Extension In The Indonesian-Malaysia Border Region. International Journal of Islamic Khazanah, 9(2), 80-84.

Siregar, C. N., Sutiadi, R., \& Epin, S. (2019). Ancaman Keamanan Nasional di Wilayah Perbatasan Indonesia: Studi Kasus Pulau Sebatik dan Tawau (Indonesia-Malaysia). Sosioglobal: Jurnal Pemikiran Dan Penelitian Sosiologi, 4(1). 
Sukamto, I. (2012). Siaran Radio-TV Malaysia Favorit Warga Perbatasan.

Sukmana, L. N., Achmad, G. N., \& ZA, S. Z. (2018). Pengaruh efektifitas iklan televisi. JURNAL MANAJEMEN. https://doi.org/10.29264/jmmn.v9i2.2477

Tanjung, Y. C., \& Marta, R. F. (2018). Nilai Eksklusivitas Dalam Karya Foto Cover Majalah Tempo Edisi 4351 Tentang Kasus Bom Sarinah 2016. Jurnal Komunikasi, 9(2), 112. https://doi.org/10.24912/jk.v9i2.181

Triwardani, R. (2013). Etnografi pemirsa dan penggunaan televisi dalam keluarga. Jurnal Ilmu Komunikasi, 9(2), 85-98. https://doi.org/10.24002/jik.v9i2

Umarela, F. H., Dwityas, N. A., \& Zahra, D. R. (2020). Representasi ideologi supremasi kulit putih dalam iklan televisi. ProTVF, 4(1), 64. https://doi.org/10.24198/ptvf.v4i1.25172

Wahab, J. A. (2012). Global Media Product and Construction of "Japanese Identity ": a Case Study of Anime on Malaysian Television. Jurnal Komunikasi: Malaysian Journal of Communication, 28(2), 1-19. https://doi.org/DOI: 10.17576/JKMJC-2018-3403-18

Widiastuti, N. (2015). Media Asing Serbu Wilayah Perbatasan.

Yudha, Y. H., Marta, R. F., \& Panggabean, H. (2021). Discourse of Faking by Civil Servant Selection Participants on YouTube. Jurnal Komunikasi Untar, 13(1), 118-132. https://doi.org/http://dx.doi.org/10.24912/jk.v13i1.11101

Yusuf, I. A. (2015). Radio di kawasan perbatasan Indonesia dalam centering the margin. Jurnal Ilmu Komunikasi, 12(2), 85-98. https://doi.org/10.24002/jik.v12i2.469 